\title{
Survey of Foliar Trichomes in Combretum Loelf. (Combretaceae) in Parts of West Africa
}

\author{
Chimezie Ekeke ${ }^{1} \&$ Ikechukwu Ozoemena Agbagwa ${ }^{1}$ \\ ${ }^{1}$ Department of Plant Science and Biotechnology, Faculty of Science, University of Port Harcourt, PMB 5323, \\ Choba, Nigeria \\ Correspondence: Chimezie Ekeke, Department of Plant Science and Biotechnology, Faculty of Science, \\ University of Port Harcourt, PMB 5323, Choba, Nigeria. Email: ekeke.uche@ uniport.edu.ng
}

Received: November 8, 2016

Accepted: January 16, 2017 Online Published: March 10, 2017

doi:10.5539/jps.v6n2p9

URL: https://doi.org/10.5539/jps.v6n2p9

\begin{abstract}
We studied the foliar trichome types, density and distribution among the genus Combretum Loelf. in parts of West Africa. Fresh and herbarium specimens were used. These specimens were fixed, peeled, trichome types identified and micro-photographed using a Leica WILD MPS 52 microscope camera on a Leitz Diaplan microscope. Generally, two major trichome groups were identified among these species studied. These include glandular trichomes: multicellular gland head with uniseriate stalk (MGU), cylindrical uniseriate clavate trichome (CUCT), unicellular gland with unisariate stalk (UGHU), cylindrical uniseriate trichome (CUT), paltate gland head (PGH) and combretaceous eglandular (non-glandular) conical trichome (long and short types). The eglandular trichome types were the most widely distributed trichome found in the species and could be used to distinguish the genus. They occurred in all the species studied except $C$. glutinosum and $C$. micranthum. Among the glandular trichomes, cylindrical uniseriate trichome was the most dominant occurring in 11 species namely; $C$. aculeatum, C. bracteatum, C. collinum subsp. binderianum, C. collinum subsp. hypopilinum, C. constrictum, C. capitatum, C. hispidum, C. nigricans, C. panuculatum, C. platypterum and C. zenkeri. This is followed by multicellular gland head with uniseriate stalk (MGU) trichome type which occurred in 9 species $(C$. bracteatum, $C$. collinum subsp. binderianum, C. collinum subsp. hypopilinum, C. constrictum, C. excelsum, C. hispidum, C. mooreanum, $C$. platypterum and C. racemosum). The trichome density varied from $1.25 \pm 0.44$ trichomes per 100 cells to 600 trichomes per 100 cells. The distribution/occurrence, density and type of these trichomes formed dependable character for delimitating Combretum species. The findings of this study showed that trichomes provide good taxonomic characters useful for in differentiating the genus Combretum in West Africa.
\end{abstract}

Keywords: Combretum, eglandular trichome, foliar trichome, Gladular trichome and trichome density

\section{Introduction}

Leaves can be classified in various ways, for example their shape and size, their texture and colour and the degree of hairiness to name but a few. These variable features are frequently reflected in different internal tissue arrangement. Some modifications are typical of plants that can grow under particular conditions, but other features may owe more to the genome than to the habitat (Airy Shaw 1985). The foliar epidermis is one of the most taxonomic characters from the biosystematics point of view. Taxonomic studies have been made on number of plant families base on their leaf epidermal characteristics (Bhatia 1984; Baranova 1972). Although taxonomists lately realized the importance of microscopic features of the epidermis, taxonomic monographs are now considered incomplete without them (Rejdali 1991).

The comparative systematic investigations of angiosperms base on the variations in trichome types have long been reported (Cowan 1950; Metcalfe \& Chalk 1950; Elena et al. 2003; Shaheen et al. 2009; Chadaporn and Pranom 2010; Ilkay et al. 2014). The morphology, types, shapes and sizes (Lawrence 1951; Stace 1980) are of taxonomic value. The use of uniseriate glandular trichomes and calcium oxalate crystals in distinguishing between the genera Diathus and Silene have been reported (Metcalfe \& Chalk 1950). Presently, (Jafari, et. al., 2002; Altaf, et. al., 2003; Agbagwa \& Okoli, 2006 ; Saheed \& Iiloh, 2010 and Kiran, et. al., 2011; Frehat, et. al., 2011; Ahmed, et. al., 2011; Abduhaman, et. al., 2011) have stated the use trichomes, their morphology (shape, size, etc) and anatomy (number of glandular head, eglandular, serriated or non serriated, etc) in plant systematics. The length, size and density of trichomes have been described among the American Combretum and concluded 
that the presence of particular type of trichome could be used to distinguish the genus (Stace 1969, 1980). However, West African species of Combretum have been basically classified based on their morphological attributes (Hutchinson \& Dalziel 1954). Therefore, this work is aimed at surveying the types and distribution on trichomes among the Combretum as complementary data to delimiting the genus.

\section{Materials and Methods}

\subsection{Source of Plant Materials}

Leaves of herbarium and fresh specimens of Combretum species used for this study were collected from Forestry Research Institute of Nigeria Herbarium (FRIN) and University of Port Harcourt Herbarium. The list and herbarium numbers of the Combretum species studied is presented in Table 1.

\subsection{Epidermal Studies}

These leaf specimens were soaked in concentrated nitric acid or trioxonitrate (v) acid $\left(\mathrm{HNO}_{3}\right)$, rinsed in distilled water, peeled with forceps, stained in $1 \%$ aqueous safranin solution and mounted in glycerin. Thereafter, the leaf epidermal characteristics were determined based on the methods of (Dilcher 1974; Cutler 1978; Metchalfe \& Chalk 1979 and Okoli \& Ndukwu 2002) and the trichome micro-photographed using a Leica WILD MPS 52 microscope camera on a Leitz Diaplan microscope.

The trichome density (abundance) is computed following the methods of Olowokudejo (1990) used in Annona species.

- $0(\mathrm{No}) \quad$ Trichomes per 100 cells glabrous

- $1-10 \quad, \quad, \quad, \quad, \quad$ glabrescent

- $11-29 \quad, \quad, \quad, \quad, \quad$, $\quad$ sparsely hairy

- $30-49 \quad, \quad, \quad, \quad, \quad$ densely hairy

- >50 $\quad, \quad, \quad, \quad, \quad$ very densely hairy 
Table 1. Information about the West African Voucher Specimens studied

\begin{tabular}{|c|c|c|c|}
\hline $\mathbf{S} / \mathbf{N}$ & Species name & Voucher information & Country \\
\hline 1 & C. aculeatum Vent. & $\begin{array}{l}\text { Dikwa division; Miss. A. McClintock; FHI 38989; 30/11/1954. } \\
\text { Yola; Girls Sch., Adamawa; M.G. Latilo; FHI 63521; 24/10/1971. } \\
\text { Yankari game Reserve; Bauchi; C. Geerling; FHI 41147; 30/10/1970 }\end{array}$ & $\begin{array}{l}\text { Cameroon } \\
\text { Nigeria } \\
\text { Nigeria }\end{array}$ \\
\hline 2 & C. acutum Laws & $\begin{array}{l}\text { River Oyinmi egde, Kabba, Kogi; Daramola \& Adebusiyi; FHI 38412; 24/10/1958. } \\
\text { Gold Coast, 3miles above Ajena, Bawku; Moton; FHI 48692; 29/11/1953. } \\
\text { North Dagemba district; FHI } 45036\end{array}$ & $\begin{array}{l}\text { Nigeria } \\
\text { Ghana } \\
\text { Ghana }\end{array}$ \\
\hline 3 & $\begin{array}{l}\text { C. bauchiense } \\
\text { Hutch. \& Diels. }\end{array}$ & $\begin{array}{l}\text { Platuea; Dogon; Platuea; Hilary; FHI 56997; 25/02/1966 } \\
\text { Bauchi; Bauchi; Holely; FHI 2067; Jan. } 1929\end{array}$ & $\begin{array}{l}\text { Nigeria } \\
\text { Nigeria }\end{array}$ \\
\hline 4 & $\begin{array}{l}\text { C. bracteatum (Laws) } \\
\text { Engl. \& Diels. }\end{array}$ & $\begin{array}{l}\text { Aponum F/R, Akure/Ondo; Odewo et al.; FHI 90845; 7/6/1979. } \\
\text { Atim, Calabar, C/R state; H.D. Onyeachusim; FHI 48155; 13/2/1964 } \\
\text { Ndoro/Umudike, Abia; J.C. Okafor \& Ariwodo; FHI 57617; 27/01/1966 } \\
\text { Owerri/Aba Rd, Imo State; Latilo; et al. FHI 71624; 17/09/1975 }\end{array}$ & $\begin{array}{l}\text { Nigeria } \\
\text { Nigeria } \\
\text { Nigeria } \\
\text { Nigeria }\end{array}$ \\
\hline 5 & $\begin{array}{l}\text { C. collinum Fresen. Subsp. } \\
\text { hypopilinum (Diels) Okafor }\end{array}$ & $\begin{array}{l}\text { Zalanya, Bauchi; Wit; Gbile \& Daramola; FHI 48905; 28/4/1972 } \\
\text { Nimbia F/R, Kaduna; Opayemi \& others; FHI 79526; 30/11/1976 } \\
\text { Bode Sadu, Jebba, Kwara; Eimunjeze \& Oguntayo; FHI 71461; 13/10/1974 }\end{array}$ & $\begin{array}{l}\text { Nigeria } \\
\text { Nigeria } \\
\text { Nigeria }\end{array}$ \\
\hline 6 & $\begin{array}{ll}\text { C. collinum } & \text { Fresen. subsp } \\
\text { binderanum } & \text { (Kotschy) Okaf }\end{array}$ & $\begin{array}{l}\text { New Bussa, Gbile; FHI 91497; } 1972 \\
\text { Ilorin, Oyo State; Oloranfemi \& Oguntayo; FHI 88536; } 1972 \\
\text { Borgu G/R, Kwara; Child, D.S; FHI 30261; } 1972 \\
\text { Abuja; Onyeachusim \& others; FHI } 100679\end{array}$ & $\begin{array}{l}\text { Nigeria } \\
\text { Nigeria } \\
\text { Nigeria } \\
\text { Nigeria }\end{array}$ \\
\hline 7 & C. mooreanum Exell & $\begin{array}{l}\text { Borgu G/R, Kwara; Child, D.S; FHI 30259; } 1972 \\
\text { New Bussa, Gbile \& others; FHI 91497; } 1975 \\
\text { Mokwa, Ngier State; FHI } 95117 \\
\text { Awum/Jebba FR; Onyeachusim \& others; FHI } 101459\end{array}$ & $\begin{array}{l}\text { Nigeria } \\
\text { Nigeria } \\
\text { Nigeria } \\
\text { Nigeria }\end{array}$ \\
\hline 8 & C. confertum (Laws) Benth & $\begin{array}{l}\text { Bendiga Ayuk, Ikom, C/R State; FHI 2817; 8/12/1950 } \\
\text { Akamkpa, C/R State; B.O. Daramola; FHI 56413; 19/10/1965 } \\
\text { Komgina, Cameroun; R.G. Lowe; FHI 18321; Dec. 1978 } \\
\text { Okobodo, Itu, C/R state; J.O. Ariwodo; FHI 88819; 1/11/1978 }\end{array}$ & $\begin{array}{l}\text { Nigeria } \\
\text { Nigeria } \\
\text { Cameroon } \\
\text { Nigeria }\end{array}$ \\
\hline 9 & C. constrictum (Benth.) Laws & $\begin{array}{l}\text { Edge of Orugi Creek, Kabba; Kogi; A.P.D. Jones; 630; 10/2/1943 } \\
\text { Oguta Lake, Imo State; Ekwuno \& others; FHI 96294; 1/9/1981 } \\
\text { Taylor Creek, Bayelsa; FHI 16524; 10/5/1940 } \\
\text { Ibadan, Oyo; Ekwuno; P; FHI 96294 }\end{array}$ & $\begin{array}{l}\text { Nigeria } \\
\text { Nigeria } \\
\text { Nigeria } \\
\text { Nigeria }\end{array}$ \\
\hline 10 & $\begin{array}{l}\text { C. cuspitatum } \\
\text { Planch. ex Benth. }\end{array}$ & $\begin{array}{l}\text { Ile Boulay Island, Ivory Coast; G.J.H. Amoshff; FHI 14055; 14/11/1964 } \\
\text { Abeokuta, Ogun State; C.F.A. Onochie; FHI 32443; 16/12/1952 } \\
\text { Benin, Bank of Abiala Creek, Edo; J.R. Charter; FHI 43263; 30/11/60 } \\
\text { Itu swamp, C/R State; L.G. Cooper; FHI 36729; 15/10/1957 }\end{array}$ & $\begin{array}{l}\text { Ivory Coast } \\
\text { Nigeria } \\
\text { Nigeria } \\
\text { Nigeria }\end{array}$ \\
\hline 11 & $\begin{array}{l}\text { C. dolichopetalum } \\
\text { Engl. \& Diels }\end{array}$ & $\begin{array}{l}\text { Benin, Edo; Onochie; FHI 39274; Nov. } 1956 \\
\text { Uyo, Etip Ediene, Akwa Ibom; Okafor \& Latilo; FHI 57764; 23/1/1966 } \\
\text { Manu F/R, Awka, Enugu; E.T. Akagu; FHI 68056A; 7/3/1974 } \\
\text { Port Harcourt, Rivers; Jones; 6194; 6/1/1974 } \\
\text { Ntalakwu-Itu, Abia; Ariwodo \& others; FHI 103536; 6/2/1982 }\end{array}$ & $\begin{array}{l}\text { Nigeria } \\
\text { Nigeria } \\
\text { Nigeria } \\
\text { Nigeria } \\
\text { Nigeria }\end{array}$ \\
\hline 12 & C. excelsum Keay & Ogoja-Ikom, C/R State; Keay; FHI 28147; 7/12/1950 & Nigeria \\
\hline 13 & C. fuscum Planch. & $\begin{array}{l}\text { Owena/Ondo, Olorumfemi \& Daramola; FHI 71047; 19/7/1974 } \\
\text { Ubukpa/Nsuka, Enugu; Okafor \& Emwiogbon; FHI 72267; 24/11/1973 } \\
\text { Oyo/Ibadan, Oyo; Keay \& Jones; FHI 14625; 30/1/1946 } \\
\text { Awka/Onitsha, Anambara State; Latilo; FHI 27310; 14/8/1950 }\end{array}$ & $\begin{array}{l}\text { Nigeria } \\
\text { Nigeria } \\
\text { Nigeria } \\
\text { Nigeria }\end{array}$ \\
\hline 14 & C. ghasalense Engl. \& Diels. & $\begin{array}{l}\text { Zaria, Kaduna; Peal; FHI 39645; 7/6/1957 } \\
\text { Damaturu, Yobe; Peal; FHI 23370; 24/6/1947 } \\
\text { Kano/Dangora; Latilo; FHI 27434; 24/4/1950 } \\
\text { Awum/Jebba FR; Onyeachusim \& others; FHI } 101455\end{array}$ & $\begin{array}{l}\text { Nigeria } \\
\text { Nigeria } \\
\text { Nigeria } \\
\text { Nigeria }\end{array}$ \\
\hline
\end{tabular}


Table 2. Continued: Information about the West African Voucher Specimens studied

\begin{tabular}{|c|c|c|c|}
\hline $\mathbf{S} / \mathbf{N}$ & Species name & Voucher information & Country \\
\hline \multirow[t]{4}{*}{15} & C. glutinosum Perr. Ex DC. & Zamfara, Zamfara State; Keay; FHI 70598; 29/6/1944. & Nigeria \\
\hline & & New Bussa; Gbile \& others; FHI 91590; 1975. & Nigeria \\
\hline & & Awum/Jebba F/R, Onyeachusim \& others; FHI 101398. & Nigeria \\
\hline & & Bauchi; Lely; FHI 2080. & Nigeria \\
\hline \multirow[t]{3}{*}{16} & C. hispidum Laws & Ibadan, Oyo; Samuel, et al .; FHI 32315; 25/1/1972. & Nigeria \\
\hline & & Ekiti 7 48N, 5 20E; Ekiti; Jones; FHI 77524; 20/1/1975. & Nigeria \\
\hline & & Ebonyi/Abakaliki, Ebonyi; Okafor \& Emwiogbon; FHI 66030; 27/2/1973. & Nigeria \\
\hline \multirow[t]{2}{*}{17} & C. insulare Engl. \& Diels. & Gambari F/R, Ibadan; Chizea, L.G.; 1975. & Nigeria \\
\hline & & Ibadan North F/R, Oyo State; Chizea; L.G.; FHI 23971; 23/02/50. & Nigeria \\
\hline \multirow[t]{4}{*}{18} & C. miranthum G. Don & Tregina Rd, Minna; Chizea, L.G.; FHI 100444; 1975. & Nigeria \\
\hline & & Ibadan, Oyo State; Lowe; J.; FHI100181. & Nigeria \\
\hline & & Minna, Niger; Onyeachusim \& others; FHI 100655. & Nigeria \\
\hline & & Katsina, Kastina State; MacGregor W.D.; FHI 2085 & Nigeria \\
\hline \multirow[t]{4}{*}{19} & C. molle R. Br. ex G. Don. & Adamawa, Adamawa; Latilo; FHI 28721; 19/11/1954 & Nigeria \\
\hline & & Zaria, Kaduna; Horum; FHI 55671; 21/12/1964 & Nigeria \\
\hline & & Gwari, Abuja; Onochie; FHI 35937; 27/5/1956 & Nigeria \\
\hline & & Yankari game Reserve, Bauchi; C. Geerling; FHI 43609; 2/13/1970 & Nigeria \\
\hline \multirow[t]{4}{*}{20} & C. nigricans var. Elliotii & Ilero/Oyo, Oyo; Latilo; FHI 58407; 23/3/1966 & Nigeria \\
\hline & Engl. \& Diels & Yankari game Reserve, Bauchi; C. Geerling; FHI 38395; 22/10/1970 & Nigeria \\
\hline & & Pategi/Kwara; Eimujeze \& Oguntayo; FHI 72829; 19/10/1974 & Nigeria \\
\hline & & Lokoja, Kogi State; Gbeli et al; FHI 64202; 20/9/1971 & Nigeria \\
\hline \multirow[t]{3}{*}{21} & C. paniculatum Vent. & Omo F/R, Ogun State; H.D. Onyeachusim; FHI 105622; Jan. 1977 & Nigeria \\
\hline & & Manu F/R, Awka, Anambara State; J.A. Emwiogbon; FHI 64000; 17/3/1972 & Nigeria \\
\hline & & Betem, Akamkpa, C/R state; J.O. Ariwodo; 28/01/1977 & Nigeria \\
\hline \multirow[t]{4}{*}{22} & C. platypterum (Welw.) & Ikom, C/R State; Tunde \& Oguntayo; FHI 86153; 1972 & Nigeria \\
\hline & Hutch. \& Diels. & Oshun-Ijesa-Ilumoba Rd; Olorunfemi; J.O.; FHI 91915; 1975 & Nigeria \\
\hline & & Enugu-Nsuka Rd; Onyeachusim \& others; FHI 100878 & Nigeria \\
\hline & & Ikom, C/R State; Latilo; FHI 31852 & Nigeria \\
\hline \multirow[t]{4}{*}{23} & C. racemosum P. Beauv. & Irewole; Tunde \& Oguntayo; FHI 85465; 1972 & Nigeria \\
\hline & & Ajibo, West Nigeria; Odewo \& others; FHI 102508 & Nigeria \\
\hline & & Udi Ngwo, Enugu; Jones; A.P.D; 260 & Nigeria \\
\hline & & Abeokuta, Ogun; J.D. Kennedy; FHI 2090 & Nigeria \\
\hline 24 & C. lamprocarpum Diels. & Daddin, Kowa; Gombe; Wit; et al..; FHI 65054; 3/5/1975. & Nigeria \\
\hline \multirow[t]{3}{*}{25} & C. zenkeri Engl. \& Diels & Ibadan, Oyo; Chizea; L.G.; FHI 99179; 1975 & Nigeria \\
\hline & & Iwo, Oyo state; Olorunfemi \& others; FHI 96534; 1975 & Nigeria \\
\hline & & Abeokuta, Ogun; A.F. Ross; FHI 2097 & Nigeria \\
\hline
\end{tabular}

\section{Results}

The trichome types, density and distribution among the 25 Combretum species studies are as follows:

\subsection{Trichome Types}

The types, density and distribution of trichomes found among the genus Combretum in parts of West Africa has been carried out. Generally, two major trichomes types (glandular and non-glandular) were identified in the genus Combretum studied. The glandular trichomes include: unicellular gland head with uniseriate stalk (UGHU), cylindrical uniseriate clavate trichome (CUCT), cylindrical uniseriae trichome (CUT), multicellular gland head with uniseriate stalk (MGU) and peltate gland head (PGH) while the non-glandular trichome comprised of the combretaceous conical trichome ECT (long and short types) (Figure 1 and Table 2).

\subsubsection{Non-glandular or Eglandular Trichomes and Distribution}

Non-glandular trichomes found in the species studied are presented in Figures 1A - 1C. It is represented by the conical trichome which is made up of the short type (Figure 1A) and long type (Figures 1B and C). The long and short trichomes were found in C. zenkeri while the long trichome type was found in C. aculeatum, C. acutum, C. 
bauchiense, C. bracteatum, C. collinum Fresen. Subsp. hypopilinum, C. collinum subsp. binderianum, C. confertum, C. constrictum, C. cuspitatum, C. dolichopetaluum, C. fuscum, C. ghasalense, C. hispidum, C. insulare, C. lamprocarpum, C. molle, C. mooreanum, C. nigricans var. elliotii, C. paniculatum, C. platypterum and $C$. racemosum (Table 1).

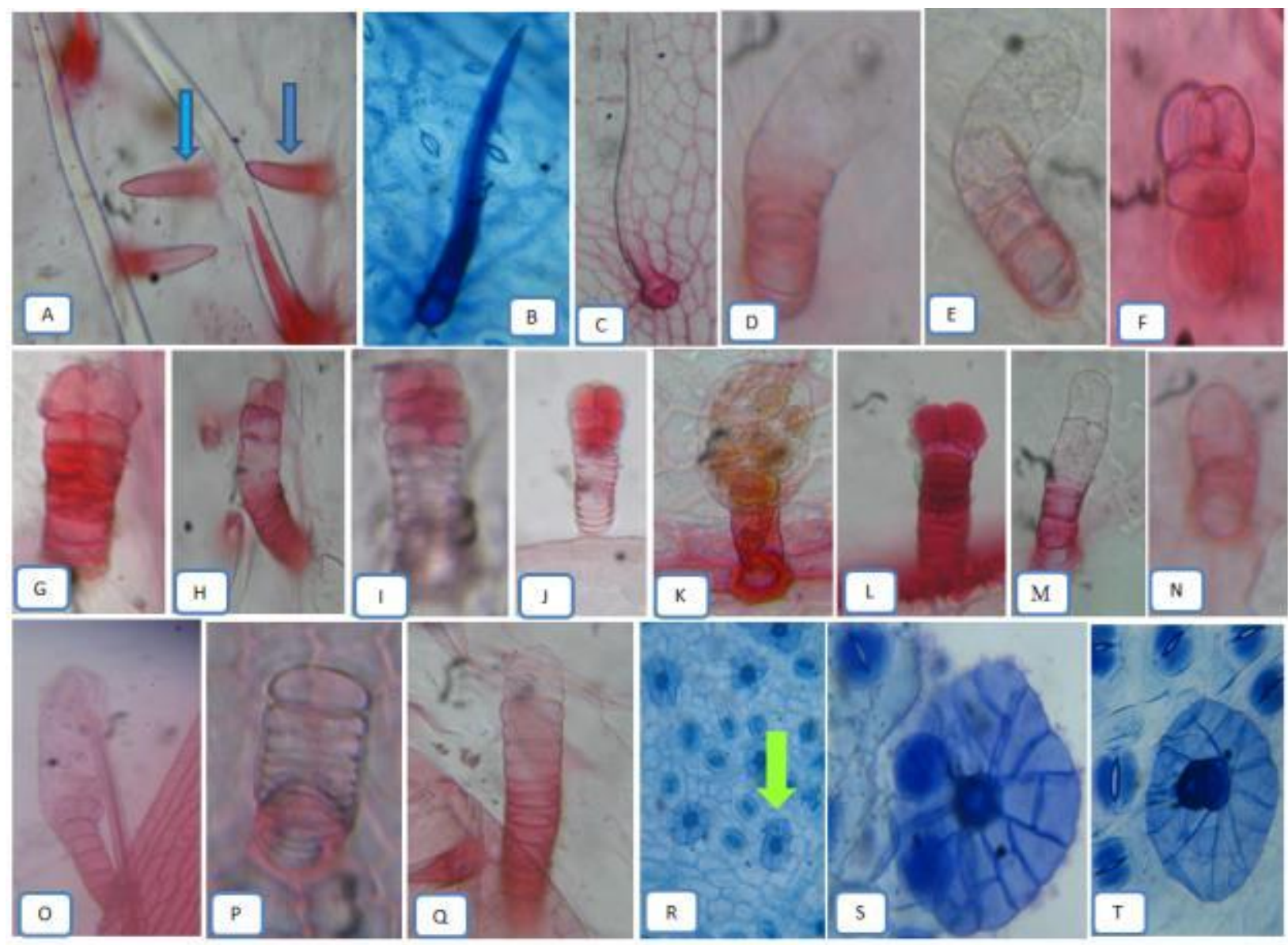

Figure 1. Types of trichomes in the Combretum species studied x1320: (A, B \& C) Eglandular conical (arrows show short trichome), (D, E, F, H, I, J, K \& L) Multicellular gland head/uniseriate stalk, (M \& N) Cylindrical uniseriate clavate trichome, (O) Unicellular glandhead/uniseriate, (P \& Q) Cylindrical uniseriate trichome and (R, $\mathrm{S} \& \mathrm{~T})$ Peltate trichome

\subsubsection{Glandular Trichome Types and Distribution}

Five glandular trichome types were identified among the Combretum species studied. These include multicellular gland head with uniseriate stalk, MGU trichome type (Figures 1D, E-L), cylindrical uniseriate clavate trichome type, CUCT (Figures 1M-N), unicellular gland with unisariate stalk, UGHU (Figure 1O), cylindrical uniseriate trichome type, CUT (Figures 1P-Q) and Paltate gland head type, PGH (Figures 1R-T). Among the glandular trichomes, multicellular gland head trichome with uniseriate stalk occurred in C. bracteatum, C. collinum subsp. binderianum, C. collinum subsp. hypopilinum, C. constrictum, C. excelsum, C. hispidum, C. mooreanum, C. platypterum and $C$. racemosum (Table 2). The unicellular gland trichome with unisariate stalk, paltate gland head trichome and cylindrical uniseriate trichome types occurred in 7 species each. Trichome with unicellular gland head and unisariate stalk occurred in C. collinum Fresen. subsp. hypopilinum, C. collinum subsp. binderianum, C. cuspitatum, C. hispidum, C. paniculatum C. platypterum and C. zenkeri. Paltate gland head trichome type occurred C. acutum, C. bauchiense, C. fuscum, C. ghasalense, C. glutinosum, C. micranthum and C. molle while the cylindrical uniseriate trichome type occurred in C. aculeatum, C. bracteatum, C. collinum Fresen. subsp. hypopilinum, C. collinum subsp. binderianum, C. constrictum, C. hispidum and C. nigricans var. elliotii. Unicellular gland head trichome with uniseriate stalk was found in $C$. aculeatum, $C$. acutum, $C$. confertum, C. constrictum, C. dolichopetaluum, C. insulare, C. lamprocarpum and C. nigricans var. elliotii) Table 1 and Figure 1. 
Table 2. Trichome types, density and their distribution among the Combretum species studied

\begin{tabular}{|c|c|c|c|c|c|c|c|c|c|}
\hline \multirow{2}{*}{ Species name } & \multicolumn{5}{|c|}{ Ganldular Trichome } & \multirow{2}{*}{$\mathbf{E C T}^{6}$} & \multirow{2}{*}{ Range } & \multirow{2}{*}{ Mean \pm STD } & \multirow{2}{*}{ Remark } \\
\hline & CUT $^{1}$ & CUCT $^{2}$ & UGHU $^{3}$ & MGU $^{4}$ & PGH $^{5}$ & & & & \\
\hline C. aculeatum & + & - & + & - & - & + & $40-90$ & $60.95 \pm 14.35^{\mathrm{k}}$ & Very densely hairy \\
\hline C. acutum & - & - & + & - & + & + & $11-28$ & $19.85 \pm 4.52^{\mathrm{f}}$ & Sparsely hairy \\
\hline C. bauchiense & - & - & - & - & + & + & $168-104$ & $138.9 \pm 15.97^{q}$ & Very densely hairy \\
\hline C. bracteatum & + & - & - & + & - & + & $1-3$ & $1.50 \pm 0.61^{\mathrm{a}}$ & Glabrescent \\
\hline C. collinum Fresen. subsp. hypopilinum & + & + & - & + & - & + & $550-600$ & $575.60 \pm 18.07^{\mathrm{s}}$ & Very densely hairy \\
\hline C. collinum subsp. binderianum & + & + & - & + & - & + & $4-10$ & $7.10 \pm 2.02^{\mathrm{d}}$ & Glabrescent \\
\hline C. confertum & - & - & + & - & - & + & $30-106$ & $58.05 \pm 21.26^{\mathrm{j}}$ & Very densely hairy \\
\hline C. constrictum & + & - & + & + & - & + & $1-8$ & $5.35 \pm 2.03^{\mathrm{c}}$ & Glabrescent \\
\hline C. cuspidatum & - & + & - & - & - & + & $1-3$ & $1.75 \pm 0.72^{\mathrm{a}}$ & Glabrescent \\
\hline C. dolichopetaluum & - & - & + & - & - & + & $1-3$ & $1.50 \pm 0.61^{\mathrm{a}}$ & Glabrescent \\
\hline C. excelsum & - & - & - & + & - & + & $70-110$ & $85.20 \pm 14.02^{1}$ & Very densely hairy \\
\hline C. fuscum & - & - & - & - & + & + & $80-150$ & $115.2 \pm 20.60^{\circ}$ & Very densely hairy \\
\hline C. ghasalense & - & - & - & - & + & + & $104-190$ & $136.95 \pm 21.44^{\mathrm{p}}$ & Very densely hairy \\
\hline C. glutinosum & - & - & - & - & + & - & $70-156$ & $107.35 \pm 24.03^{\mathrm{n}}$ & Very densely hairy \\
\hline C. hispidum & + & + & - & + & - & + & $26-90$ & $54.60 \pm 20.01^{\mathrm{i}}$ & Very densely hairy \\
\hline C. insulare & - & - & + & - & - & + & $2-8$ & $4.45 \pm 1.90^{\mathrm{b}}$ & Glabrescent \\
\hline C. lamprocarpum & - & - & + & - & - & + & $3-9$ & $6.00 \pm 1.81^{\mathrm{c}}$ & Glabrescent \\
\hline C. micranthum & - & - & - & - & + & - & $33-81$ & $47.80 \pm 14.60^{\mathrm{g}}$ & Densely hairy \\
\hline C. molle & - & - & - & - & + & + & $76-198$ & $143.0 \pm 37.16^{\mathrm{r}}$ & Very densely hairy \\
\hline C. mooreanum & - & - & - & + & - & + & $4-12$ & $7.10 \pm 0.02^{\mathrm{d}}$ & Glabrescent \\
\hline C. nigricans var. elliotii & + & - & + & - & - & + & $31-81$ & $51.60 \pm 14.37^{\mathrm{h}}$ & Very densely hairy \\
\hline C. paniculatum & - & + & - & - & - & + & $6-10$ & $8.40 \pm 1.27^{\mathrm{e}}$ & Glabrescent \\
\hline C. platypterum & - & + & - & + & - & + & $1-2$ & $1.25 \pm 0.44^{\mathrm{a}}$ & Glabrescent \\
\hline C. racemosum & - & - & - & + & - & + & $4-12$ & $7.10 \pm 2.02^{\mathrm{d}}$ & Glabrescent \\
\hline C. zenkeri & - & + & - & - & - & + & $42-163$ & $90.70 \pm 44.50^{\mathrm{m}}$ & Very densely hairy \\
\hline
\end{tabular}

${ }^{1}$ Cylindrical uniseriate trichome, ${ }^{2}$ Cylindrical uniseriate clavate trichome, ${ }^{3}$ Unicellular gland head/ uniseriate stalk, ${ }^{4}$ Multicellular glandhead/ uniseriate stalk, ${ }^{5}$ Peltate gland head, ${ }^{6}$ Eglandular conical trichome, Note: + = Present, - = absent; values followed by the same letter in a column are not significantly different at $5 \%$ level using LSD.

\subsection{Trichome Density and Leaf Surface}

The trichome density in the Combretum species sampled varied from $1.25 \pm 0.44$ trichomes per 100 cells for $C$. platypterum (glabrescent) to $>500$ trichomes per 100 cells for $C$. collinum subsp hypopilinum (very densely hairy). The leaf surface of most the species are glabrescent. The trichome densities of these species include: $C$. platypterum, 1.25 $\pm 0.44 ; C$. bracteatum, $1.50 \pm 0.61 ; C$. dolichopetaluum, $1.50 \pm 0.61 ; C$. cuspitatum, $1.75 \pm 0.72 ; C$.

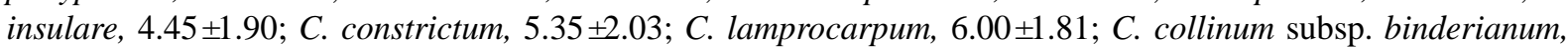

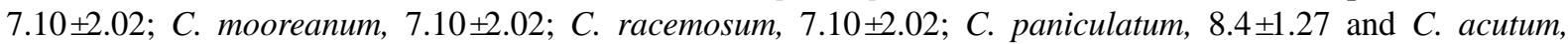
$19.85 \pm 4.52$. These species are sparsely hairy while $C$. micranthum is densely hairy with trichome density of 47.8 \pm 14.60 . Other species of this genus studied are very densely hairy and their trichome densities are as follows:

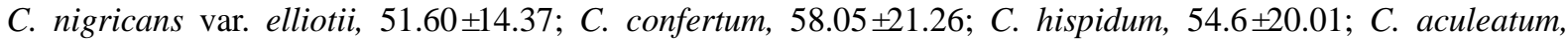

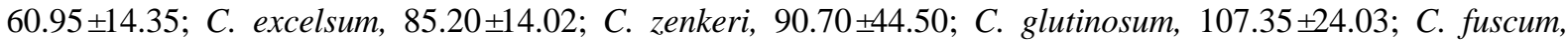

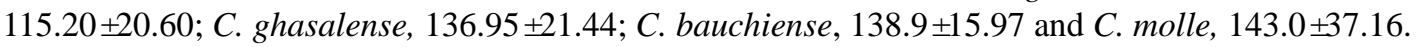

\section{Discussion}

The foliar trichome amongst members of the genus Combretum in West Africa is scarcely studied. In this work we surveyed the occurrence of different trichome types, the degree of hairiness on leaf surfaces/trichome densities of these species. The non-glandular trichome types were the most diversified and widely distributed trichome found in the species studied and could be used to distinguish members of this genus. For instance, among the species studied, this trichome type was not observed in two species namely; $C$. glutinosum and C. micranthum. This character therefore makes the two species distinct from the other ones and the species are further delimited based on their trichome densities (Table 2). C. glutinosum is very densely hairy with trichome of $70-156(107.35 \pm 24.03)$ trichomes per 100 cells while $C$. micranthum is densely hairy with trichome density of $33-81(47.80 \pm 14.60)$ trichomes per 100 cells. This further explains the occurrence of these species in different ecological zones (Ekeke, 2013). This is in line with the work of Stace (1980) who noted that the length, size and density of trichomes could 
be influenced by environmental conditions. Also, the presence of a particular type of trichome has been used in the taxonomy of Combretum (Stace 1980). Since environmental conditions can influence the length and density of trichome, it can be used in placing these species into different geographical or ecological zones.

Five glandular trichome types were identified among the Combretum species studied (Table 2). Among the glandular trichomes, CUT was the most dominant occurring in 11 species namely; $C$. aculeatum, $C$. bracteatum, $C$. collinum subsp. binderianum, C. collinum subsp. hypopilinum, C. constrictum, C. capitatum, C. hispidum, C. nigricans, $C$. panuculatum, $C$. platypterum and $C$. zenkeri. This is followed by multicellular gland head with uniseriate stalk (MGU) trichome type occurring in 9 species (C. bracteatum, $C$. collinum subsp. binderianum, $C$. collinum subsp. hypopilinum, C. constrictum, C. excelsum, C. hispidum, C. mooreanum, $C$. platypterum and $C$. racemosum) Table 2 . This showed that these species are related however, variation in number gland heads and the morphology of the trichomes could be used to further distinguish them. For instance, among these Combretun species with uniseriate trichome, C. collinum Fresen. subsp. hypopilinum, C. collinum subsp. binderianum and $C$. hispidum have MGU and ECT but the trichome densities differed from one species to the other. C. collinum subsp. binderianum is glabrescent while $C$. collinum Fresen. subsp. hypopilinum and $C$. hispidum are very densely hairy. Furthermore, $C$. collinum Fresen. subsp. hypopilinum has more trichomes than C. hispidum. Also, C. platypterum and C. paniculatum have CUCT and are glabrescent however; the presence of MGU in C. platypterum distinguishes it from C. paniculatum. Similarly, C. bracteatum and C. constrictum have CUT, but $C$. constrictum has UGHU and MGU which are not found in $C$. bracteatum. In the same vein, $C$. zenkeri and C. cuspidatum could be distinguished base on the density of trichomes on the leaf surface (Table 2). Though these two species have CUCT, $C$. zenkeri has trichome density of $42-163(90.70 \pm 44.50)$ trichomes per 100 cells while $C$. cuspidatum has trichome density of $1-3(1.75 \pm 0.72)$ trichomes per 100 cells. C. mooreanum and $C$. racemosum have only two trichome types (MGU and ECT). The analysis of variance of the trichome densities showed that there is significant difference in densities of the trichomes among the species studied (Table 2). This suggests that the variation in trichome density could be used in delimitating the genus and could complement the existing data on these species.

Trichomes have been reported to have contributed immensely to the taxonomy of the genus Combretum in particular and Combretaceae family at large. The unicellular combretaceous trichome type has been reported among the American species (Stace 1961, 1965) and glandular trichome with peltate head or without peltate head (stalk gland) (Solereder 1908; Stace 1969a, b, 1980; Metcalfe \& Chalk 1979; Patricia 2002). Similarly, the trichomes recorded in this report are the same as those in the previous reports. Stace (1969) noted the value of the leaf epidermal characteristics and particularly the glandular trichomes in the identification and classification of the 37 species of Combretum in America. He used the wide range of trichome types found among the species to differentiate groups of species corresponding closely with the 11 sections recognized by Exell, rather than distinguishing individual species and suggested that these trichomes have great taxonomic value as that of any other organ in the genus. Also, Jordaan et al. (2011) reported peltate trichome in South African Combretum species as important taxonomic character. Trichome morphology, densities and types have been employed in distinguishing other genera other than Combretum. These have been employed to differentiate Ajuga in Turkey (Ilkay et al. 2014), Croton in Thailand (Chadaporn \& Pranom 2010) and Hibiscus (Shaheen et al. 2009).

\section{Conclusion}

The findings in this study showed that trichomes in combination with other taxonomic characters can be used in differentiating the genus Combretum in West Africa and supports previous works on other members of this genus from other parts of the world.

\section{Acknowledgement}

The authors wish to appreciate and thank the staff of the Forestry Institute of Nigeria (FRIN) and Department of Plant Science and Biotechnology, University of Port Harcourt for their assistance in providing laboratory equipment and enabling environment for carrying out this research.

\section{References}

Agbagwa, I. O., \& Bosa, B. E. (2006). Leaf Epidermal Micromorphology in the Systematics of Abrus (Papilionaceae) in Parts of Tropical West Africa. Asian Journal of Plant Science, 5(1), 41-49. https://doi.org/10.3923/ajps.2005.652.659

Airy-Shaw, H. K. (1985). A dictionary of the flowering plant. $8^{\text {th }}$ Edn., Cambridge University Press, London.

Altaf, A. D., Bokhari, T. Z., Saeed, A. M., \& Rubina, A. (2003). Epidermal Morphology of Some Members of Family Boraginaceae in Baluchistan. Asian Journal of Plant Sciences, 2(1), 42-47. 
https://doi.org/10.3923/ajps.2003.42.47

Baranova, M. (1972). Systematic anatomy of the leaf epidermis in the Magnoliaceae and some related families. Taxon, 21, 447-467. BIO: http://www.jse.ac.cn/wenzhang/aps06137.pdf

Bhatia, R. C. (1984). Foliar Epidermal Studies of Heliotropium supinum L. Folia Geobot. Phytotaxon, 19, 381-385. https://doi.org/10.1007/BF02853177

Chadaporn, S., \& Pranom, C. (2010). A morphological survey of foliar trichomes of Croton L. (Euphorbiaceae) in Thailand. Thai For. Bull. (BOT.), 38, 167-172. http://www.tci-thaijo.org/index.php/ThaiForestBulletin/article/viewFile/24427/20792

Cowan, J. L. (1950). The Rhododendron leaf; a study of the epidermal appendages. Oliver and Boyd, Edinburgh.

Cutler, D. F. (1978). Applied Plant Anatomy. Longman Inc, New York, USA.

Dilcher, D. L. (1974). Approaches to the identification of angiosperm leaf remains. Bot. Rev., 40, 1-157. https://doi.org/10.1007/BF02860067

Ekeke, C. (2013). Taxonomic studies on the genus Combretum Loefl. In Nigeria. PhD. Thesis. University of Port Harcourt.

Elena, V., Juha-Pekka, S., Julia, K., \& Kalevi, P. (2003). Comparative analysis of leaf trichome structure and composition of epicuticular flavonoids in Finish Birch Species. Annals of Bot., 91, 643-655. https://doi.org/10.1093/aob/mcg070

Ferhat, C., Ahmet, K., Zeynep, A., \& Musa, D, (2011). Morphology, anatomy and trichome properties of Lamium truncatum Boiss. (Lamiaceae) and their systematic implications. Australian Journal on Crop Science (AJCS), 5(2), 147-153. http://www.cropj.com/celep_5_2_2011_147_153.pdf

Hutchinson, J., \& Dalziel, J. M. (1954). Flora of West Tropical Africa. Revised by Keay, R. W. J. Vol. I Part I. Crown Agents for Oversea Governments and Administrations, London.

Ilkay, Ö. Ç., Arzu, C., \& Cengiz, Y. (2014). Trichome morphology of ajuga orientalis 1. (Lamiaceae) from Turkey. Bangladesh J. Bot., 43(1), 91-95. https://doi.org/10.3329/bjb.v44i1.22721

Jafari, A., Zokai, M., \& Fathi, Z. (2002). A Biosystematical Investigation on Silene L. species in North East of Iran. Asi. J. Pl. Sci., 7(4), 394-398.

Jordaan, M., van Wyk, A. E., \& Maurin, O. (2011). A conspectus of Combretum (Combretaceae) in southern Africa, with taxonomic and nomenclatural notes on species and sections. Bothalia, 41(1), 135-160. http://www.abcjournal.org/index.php/ABC/article/viewFile/36/36

Lawrence, G. H. M. (1951). Taxonomy of vascular plants. Macmillan Co., New York

Metcalfe, C. R., \& Chalk, L. (1950). Anatomy of dicotyledons, Vol. 1, Oxford University Press, New York.

Metcalfe, C. R., \& Chalk, L. (1979). Anatomy of the dicotyledon, vol. 1: Systematic anatomy of the leaf and stem. Oxford University Press, New York.

Okoli, B. E., \& Ndukwu, B. C. (2002). Procedure for the Observation of Living tissues (Vital Observation) in Field, Herbarium and Laboratory Techniques. Edited by Okoli, B. E. Mbeyi and associates Nig. Ltd. Port Harcourt. 34-38.

Olowokudejo, J. D. (1990). Comparative morphology of leaf epidermis in the genus Annona (Annonaceae) in West Africa. Phytomorph., 4(3\&4), 407-422.

Patricia, M. T. (2002). A contribution to the leaf and young stem anatomy of the Combretaceae. Botanical Journal of the Linnean Society, 138, 168-196. http://onlinelibrary.wiley.com/doi/10.1046/j.1095-8339.2002.138002163.x/pdf

Rejdali, M. F. L. S. (1991). Leaf micro-morphology and anatomy of North African species of Sideritis L. (Lamiaceae). Bot. J. Linn. Soc., 107, 67-77

Saheed, S. F., \& Liloh, H. C. (2010). A taxonomic study of some species of Cassiinae (Leguminosae) using leaf epidermal characters. Not. Bot. Hort. Agrobot, 38, 21-27.

Shaheen, N., Ajab, M., Hayat, M. Q, \& Yasmin, G. (2009). Diversity of Foliar trichomes and their systematic relevance in the genus Hibiscus (Malvaceae). Int. J. Agric. Biol., 11, 279-284.

https://www.fspublishers.org/published_papers/61916_..pdf

Solereder, H. (1908). Systematic anatomy of dicotyledons: a handbook for laboratories of pure and applied botany. 
Clarendon Press, Oxford.

Stace, C. A. (1961). Cuticular characters as an aid to the taxonomy of the South-West African species of Combretum. Mitteilungen der Botanischen Staatssmmlung Munchen, 4, 9-19.

Stace, C. A. (1965). The significance of leaf epidermis in the taxonomy. Bull. Br. Mus. (Nat. Hist.) Bot., 4(1), $1-78$.

Stace, C. A. (1969a). The significance of leaf epidermis in the taxonomy of Combretaceae II: The genus of Combretum subsp Combretum in Africa. Botanical Journal of the Linnean Society, 62, 131-168.

Stace, C. A. (1969b). The significance of leaf epidermis in the taxonomy of Combretaceae III: The genus of Combretum in America. Brittinia, 12, 131-143.

Stace, C. A. (1973). The significance of leaf epidermis in the taxonomy of Combretaceae IV: The genus of Combretum in Asia. Botanical Journal of the Linnean Society, 66, 97-115.

Stace, C. A. (1980). The significance of leaf epidermis in the taxonomy of Combretaceae V: The genus of Combretum subsp. Cacoucia in Africa. Botanical Journal of the Linnean Society, 81, 185-203.

\section{Copyrights}

Copyright for this article is retained by the author(s), with first publication rights granted to the journal.

This is an open-access article distributed under the terms and conditions of the Creative Commons Attribution license (http://creativecommons.org/licenses/by/4.0/). 